\title{
The Apraxia battery for Adults - 2 (ABA - 2). (A second pilot study and validation of the test in aphasic Greek population)
}

\author{
Dionisios Tafiadis ${ }^{1,2,3^{*}}$, Makrina Keloglou ${ }^{1,2,3}$, Aglaia Zafeiri ${ }^{1,2,3}$, Maria Tafiadi ${ }^{1,2,3}$ \\ From $1^{\text {st }}$ International Congress on Neurobiology and Clinical Psychopharmacology and European \\ Psychiatric Association Conference on Treatment Guidance \\ Thessaloniki, Greece. 19-22 November 2009
}

\section{Background}

Purpose of present study was the second pilot validation and evaluation for Greek population of Apraxia Battery for Adults - 2 (ABA - 2). ABA was originally created by Brownell and Dabul, in 2000, and it is used as diagnostic scale for adult Apraxia of speech and measures the skills in the apraxic population.

\section{Materials and methods}

The commercial battery was administered to 37 participants 20 normal (as control group) and 17 with aphasic pathology, recruited from Greek health settings, aged from 38 - 70 years. The collection of sample became independent from socio-economic criteria, and they did not present any other pathology which probably influence the output in the particular scale.

\section{Results}

The analysis of the data revealed statistically significant difference to the results obtained is generally consistent with the results reported in the US. Also statistically significant differences were found between the results obtained between normal and pathological groups in all diagnostic categories. We also saw that the particular scale is not influenced by various parameters such as sex. The reliability of scale had a general cohesion Reliability Coefficients 6 items Alpha $=.853$ Standardized item alpha $=.913$.

\section{Conclusions}

The battery appears to be sensitive to Greek reality. From the control of validity and reliability in this sample

${ }^{1}$ Department of Speech and Language Therapy, T.E.I. of Epirus, Ioannina, loanninon, Greece we saw that the Greek version of ABA - 2 it is a valid and reliable scale, and presents satisfactory criterion and content validity as the participants assessed demonstrated clear patterns of answers and deficits.

\section{Acknowledgements}

We would like to thank the Neurological Department of Papageorgiou Hospital (Thesaloniki, Greece) for recruting aphasic subjects.

\section{Author details}

'Department of Speech and Language Therapy, T.E.I. of Epirus, loannina, Ioanninon, Greece. ${ }^{2}$ Department of Neural Sciences and Sensory Organs (School of medicine), University of loannina, loannina, loanninon, Greece. ${ }^{3}$ Department of Mathematics, National and Kapodistrian University of Athens, Athens, Attika, Greece.

Published: 22 April 2010

doi:10.1186/1744-859X-9-S1-S120

Cite this article as: Tafiadis et al:: The Apraxia battery for Adults - 2 (ABA - 2). (A second pilot study and validation of the test in aphasic Greek population). Annals of General Psychiatry 2010 9(Suppl 1):S120.

Submit your next manuscript to BioMed Central and take full advantage of:

- Convenient online submission

- Thorough peer review

- No space constraints or color figure charges

- Immediate publication on acceptance

- Inclusion in PubMled, CAS, Scopus and Google Scholar

- Research which is freely available for redistribution 